\title{
ANALISIS EFISIENSI BUDIDAYA TANAMAN LIDAH BUAYA DI KELURAHAN MAHARATU KECAMATAN MARPOYAN DAMAI KOTA PEKANBARU
}

\author{
YENI KUSUMAWATY, SUSY EDWINA DAN EVY MAHARANI \\ Jurusan Agribisnis Fakultas Pertanian Universitas Riau \\ Kampus Binawidya Simpang Baru Kecamatan Tampan Pekanbaru \\ Email: yeni.kusumawaty@unri.ac.id
}

\begin{abstract}
ABSTRAK
Budidaya tanaman lidah buaya telah dilakukan sejak tahun 2007 di Kelurahan Maharatu, Kecamatan Marpoyan Damai di Kota Pekanbaru oleh kelompok tani Panca Karya dan Karya Makmur. Komoditas lidah buaya memiliki prospek yang baik. Namun terdapat berbagai masalah dalam subsistem pemasaran produk pertaniannya seperti kemampuan pasar yang terbatas untuk menyerap produk lidah buaya, yang telah menyebabkan petani mengurangi produksinya. Dalam kondisi ini, perlu dilakukan analisis budidaya lidah buaya untuk mempelajari efisiensi usahatani lidah buaya. Permasalahan penelitian adalah sebagai berikut: 1) identifikasi sistem agribisnis lidah buaya yang saat ini dilaksanakan oleh petani, dan 2) analisis biaya produksi, nilai penyusutan peralatan, pendapatan petani, dan efisiensi usahatani aloe vera. Metode yang digunakan dalam penelitian ini adalah survei pada petani lidah buaya. Kesimpulan: 1) usahatani cukup menguntungkan dengan laba bersih Rp 154.925 untuk produksi rata-rata Rp 325.075 (Panca Karya) dan laba bersih sebesar Rp 360.845 untuk produksi rata-rata $\mathrm{Rp} 439.154$ (Karya Makmur) untuk satu siklus produksi per bulan dan 2) Nilai RCR usahatani lidah buaya adalah 1,47 pada kelompok tani Panca Karya dan 1,82 pada kelompok tani Karya Makmur, sehingga usahatani dianggap efisien.
\end{abstract}

\section{Kata kunci: analisis efisiensi, budidaya, lidah buaya}

\section{PENDAHULUAN}

Sektor pertanian termasuk agribisnis berperan penting dalam perekonomian nasional, diantaranya dalam mewujudkan ketahahanan pangan, penyediaan lapangan kerja dan pemerataan pendapatan (Ponto dkk, 2015). Usaha agribisnis mampu memberikan pendapatan tunai bagi masyarakat dengan nilai jualnya yang tinggi, tersedianya sumberdaya lahan dan teknologi, serta potensi serapan pasar dalam negeri dan internasional yang meningkat. Ketersediaan sumberdaya hayati berupa jenis tanaman dan sumberdaya lahan, apabila dikelola optimal akan menjadi kegiatan ekonomi yang bermanfaat untuk penanggulangan kemiskinan (Direktorat Jenderal Hortikultura, 2007). 
Pengembangan sentra wilayah agribisnis disektor pertanian pada hakekatnya merupakan kegiatan awal untuk memacu pembangunan bidang ekonomi di suatu wilayah. Secara bertahap berkembangnya kegiatan produksi komoditas pertanian diupayakan untuk dapat diikuti oleh muncul dan berkembangnya kegiatan-kegiatan ekonomi terkait, baik secara horizontal maupun vertikal, serta pengadaan jasa di sekitarnya sehingga diharapkan menumbuhkan dinamika perekonomian wilayah (Soemarsono, 2002).

Pengembangan agribisnis disetiap daerah jangan hanya puas pada pemanfaatan kelimpahan sumber daya yang ada (factor driven) atau mengandalkan keunggulan komparatif (comparative advantage) seperti sekarang ini, tetapi secara bertahap harus dikembangkan ke arah agribisnis yang didorong oleh modal man-made (capital drive) dan kemudian kepada agribisnis yang didorong oleh inovasi (innovation driven). Dengan perkataan lain, keunggulan komparatif agribisnis pada setiap daerah ditranformasi menjadi keunggulan bersaing (competitive advantage) melalui pengembangan mutu sumber daya manusia, teknologi, kelembagaan dan organisasi ekonomi lokal yang telah ada di tiap daerah (Sumodiningrat, 2000).

Pembangunan sistem agribisnis harus mampu mengkoordinasikan kegiatan dan pendanaan yang tersebar secara parsial dan dirangkai dalam suatu kegiatan yang saling bersambung, membentuk sistem agribisnis yang utuh. Untuk itu koordinasi perencanaan dan pengendalian sejak ditingkat provinsi hingga tingkat lokasi, yang menjamin terfokusnya berbagai sumberdaya dan dana untuk pengembangan sentra dimaksud merupakan aspek yang sangat penting. Sehubungan dengan hal itu peranan Pemerintah Daerah sebagai pemegang kebijakan yang mengatur gerak pembangunan daerah sangat penting.

Pembangunan pertanian yang di dalamnya mencakup pengembangan sistem agribisnis, mulai dari subsistem agribisnis hulu sampai hilir serta subsistem penunjang, harus saling terkait. Kelemahan pada subsistem agribisnis hulu, seperti benih dan sarana produksi, akan berdampak terhadap produksi; kelemahan di sektor hilir menyebabkan ketidakmampuan untuk memperoleh nilai tambah dan produk rentan terhadap fluktuasi harga (Saragih 2001).

Dalam pengembangan agribisnis hortikultura secara keseluruhan, usaha produksi yang berkaitan dengan pilihan varietas dan pilihan jenis komoditas masing-masing memiliki peluang ekonomi yang besar, tergantung dari lokasi, segmen target konsumen, ketersediaan sumberdaya dan kemampuan modal dari pelaku usaha. Salah satu komoditi yang berprospek

86 Analisis Efisiensi Budidaya Tanaman Lidah Buaya Di Kelurahan Maharatu Kecamatan Marpoyan Damai Kota Pekanbaru 
dikembangkan adalah tanaman lidah buaya. Menurut Zulfita (2012), tanaman lidah buaya merupakan salah satu komoditi unggulan di Provinsi Kalimantan Barat. Tanaman ini jika dibudidayakan secara optimal dapat menghasilkan pelepah daun berukuran besar dengan berat mencapai $2,7 \mathrm{~kg}$ per pelepah.

Perkembangan sektor pertanian di daerah Riau sampai saat ini cukup mengembirakan dari aspek produksi, namun pendapatan petani belum meningkat sebagai mana diharapkan karena terbatasnya wilayah pemasaran hasil produksi pertanian. Kondisi demikian juga terjadi pada petani lidah buaya di Riau. Di Provinsi Riau khususnya Kabupaten Siak jumlah wilayah yang tersedia untuk pengembangan perkebunan lidah buaya adalah 1.500 ha, 2 ha dari total luas lahan tersebut telah ditanami lidah buaya (Anonim, 2010).

Di kota Pekanbaru Provinsi Riau, budidaya tanaman lidah buaya sudah dilaksanakan pada tahun 2007 tepatnya di Kelurahan Maharatu Kecamatan Marpoyan Damai Pekanbaru pada kelompok tani Panca Karya dan Karya Makmur dengan luas areal pertanaman lidah buaya sekitar 0,25 ha dengan produksi per minggu mencapai 100 - $150 \mathrm{~kg}$ dengan harga $\mathrm{Rp}$ 4000 per kg, namun sejak tahun 2009 produksi lidah buaya sudah menurun dengan jumlah produksi sekitar $50 \mathrm{~kg}$ per minggu. Hal ini terjadi karena dipengaruhi oleh beberapa permasalahan seperti luas lahan yang relatif sempit dan ditambah lagi dengan alih fungsi lahan menjadi tanaman sayuran, kemampuan pasar menyerap produksi lidah buaya yang terbatas.

Selain faktor pasar dan luas lahan, faktor penting dalam subsistem agribisnis adalah partisipasi masyarakat. Menurut Murtiyanto (2011) di dalam Rajagukguk dkk (2013), keberhasilan pembangunan agribisnis tidak bisa terlepas dari partisipasi masyarakat tani. Pembangunan yang dilaksanakan oleh pemerintah tentunya bertujuan untuk mencapai masyarakat yang sejahtera sehingga posisi masyarakat merupakan posisi yang penting dalam proses pelaksanaan pembangunan yang dilaksanakan oleh pemerintah.

Berdasarkan survey awal, jumlah petani di kelompok tani Panca Karya sekitar 25 orang, namun petani yang membudidayakan lidah buaya saat ini berkurang menjadi 1 orang, sedangkan jumlah petani di kelompok tani Karya Makmur sebanyak 40 orang dan petani yang membudidayakan lidah buaya sebanyak 3 orang dan hanya 2 orang yang sudah berproduksi sedangkan 1 orang lagi belum berproduksi. Maka jumlah petani yang 
membudidayakan lidah buaya dan masih berproduksi sebanyak 3 petani dengan harga lidah buaya Rp. 4000/kg dengan produksi lidah buaya saat ini sekitar $50 \mathrm{~kg}$ per minggu.

Walaupun menghadapi kendala alih fungsi lahan dan partisipasi petani, budidaya tanaman lidah buaya kelompok tani Panca Karya dan Karya Makmur yang ada di Kelurahan Maharatu Kecamatan Marpoyan Damai memiliki potensi untuk dikembangkan karena memiliki prospek dan nilai ekonomi yang tinggi, dan pola usahatani yang dilakukan oleh kelompok tani saat ini adalah tumpang sari dan monokultur.

Dilihat dari potensi produksi dan harga, komoditi lidah buaya mempunyai prospek yang sangat menjanjikan. Namun dalam subsistem pemasaran hasil pertanian lidah buaya terdapat berbagai masalah seperti kemampuan pasar menyerap produksi lidah buaya masih terbatas dalam hal wilayah pemasaran dan kuantitasnya sehingga petani menurunkan jumlah produksinya. Pada keadaan ini dibutuhkan analisis untuk mengetahui efisiensi usaha budidaya tanaman lidah buaya dan prospek ke depannya. Permasalahan yang dikaji dalam penelitian ini adalah:

1. Bagaimanakah penerapan sistem agribisnis budidaya lidah buaya yang dilakukan petani

2. Bagaimanakah analisis biaya produksi, nilai penyusutan alat, pendapatan petani, efisiensi usahatani lidah buaya pada pola monokultur dan tumpang sari

\section{METODE PENELITIAN}

Penelitian ini dilaksanakan di Kecamatan Marpoyan Damai Kelurahan Maharatu pada kelompok tani Panca Karya dan Karya Makmur. Lokasi penelitian ini dipilih berdasarkan atas pertimbangan karena merupakan salah satu penghasil lidah buaya di kota Pekanbaru.

Metode yang digunakan pada penelitian ini adalah metode survei, petani sebagai informan. Data yang digunakan meliputi data primer dan sekunder. Pengumpulan data primer pada petani lidah buaya dan usahatani. Data primer diperoleh langsung dengan cara wawancara dengan alat kuesioner. Data primer meliputi profil petani/informan (nama, umur, jenis kelamin, tingkat pendidikan, pengalaman berusahatani, tanggungan keluarga, luas tanam/lahan), penggunaan faktor produksi, jumlah produksi, harga, nilai penyusutan alat produksi usahatani lidah buaya serta sistem pemasaran yang dilakukan petani lidah buaya.

Pengambilan responden petani lidah buaya sebanyak 3 responden, 1 orang petani dari Kelompok tani Panca Karya dengan luas lahan \pm 0,25 ha (1250 rumpun lidah buaya) pola 
monokultur dan 2 orang petani dari Kelompok tani Karya Makmur dengan luas lahan kurang dari 0,25 ha (100 - 150 rumpun lidah buaya) pola tumpang sari. Pengambilan responden ini secara purposive (sengaja) karena tidak ada lagi petani yang membudidayakan lidah buaya pada Kelompok tani Panca Karya dan Karya Makmur. Adapun informasi yang akan dikumpulkan meliputi subsistem sarana produksi, susbsistem produksi/usahatani, subsistem pengolahan hasil pertanian, subsistem pemasaran hasil pertanian, dan subsistem pendukung/penunjang (Yasin, 2002).

Analisis data secara kualitatif dan kuantitatif. Analisis kualitatif untuk menggambarkan karakteristik petani lidah buaya, melihat penerapan sistem agribisnis lidah buaya. Sedangkan untuk menghitung biaya produksi, penyusutan alat, pendapatan petani, dan efisiensi usahatani, digunakan analisis kuantitatif sebagai berikut:

a. Analisis Biaya Produksi

Untuk mengetahui biaya produksi digunakan rumus Soekartawi (2002), yaitu :

\section{$\mathrm{TC}=\mathrm{TFC}+\mathrm{TVC}$}

Keterangan:

$\mathrm{TC}=$ biaya total $(\mathrm{Rp} / \mathrm{tahun} / \mathrm{bulan}$ proses produksi)

TFC = biaya tetap total ( $\mathrm{Rp} /$ tahun proses produksi)

TVC = biaya variabel $(\mathrm{Rp} / \mathrm{bulan}$ proses produksi)

b. Nilai Penyusutan Alat

Untuk menghitung penyusutan alat dengan metode garis lurus Soekartawi (1995) yaitu:

$$
\mathbf{D}=\underline{\mathbf{N B}}-\mathbf{N S}
$$

\section{UE}

Keterangan:

$\mathrm{D}=$ Nilai Penyusutan Alat $(\mathrm{Rp} / \mathrm{musim}$ tanam $)$

NB = Nilai Beli Alat (Rp/unit)

NS = Nilai Sisa (Rp/unit)

$\mathrm{UE}=$ Umur Ekonomis (tahun/bulan proses produksi)

c. Pendapatan Kotor

89 Analisis Efisiensi Budidaya Tanaman Lidah Buaya Di Kelurahan Maharatu Kecamatan Marpoyan Damai Kota Pekanbaru 
Untuk menghitung pendapatan kotor atau penerimaan digunakan rumus Soekartawi (1995), yaitu:

\section{$\mathbf{T R}=\mathbf{P y} \times \mathbf{Y}$}

Keterangan:

$\mathrm{TR}=$ penerimaan total $(\mathrm{Rp} / \mathrm{bulan}$ proses produksi $)$

$\mathrm{P} \quad=$ harga per unit $(\mathrm{Rp} / \mathrm{kg})$

$\mathrm{Y} \quad=$ jumlah produksi $(\mathrm{Kg} / \mathrm{bulan}$ proses produksi)

d. Pendapatan Bersih

Untuk menghitung pendapatan bersih usahatani digunakan rumus Soekartawi (1995), yaitu:

$$
\begin{aligned}
& \Pi=\text { TR }- \text { TC } \\
& \Pi=\text { Y.Py }-(\text { TVC }+ \text { TFC }) \\
& \Pi=\text { Y.Py }-((\text { X1 + X2 + X3 + X4 + X5 + X6 + D })+(X 7)
\end{aligned}
$$

Dimana:

$\Pi \quad=$ Pendapatan bersih usahatani lidah buaya (Rp/bulan proses produksi)

$\mathrm{Y}=$ Jumlah produksi lidah buaya $(\mathrm{kg} / \mathrm{bulan}$ proses produksi)

Py = Harga produksi lidah buaya $(\mathrm{Rp} / \mathrm{kg})$

$\mathrm{VC}=$ Jumlah panggunaan biaya variabel ( $\mathrm{Rp} / \mathrm{bulan}$ proses produksi)

TFC = Jumlah penggunaan biaya tetap (Rp/tahun proses produksi)

$\mathrm{X} 1=$ Total biaya bibit lidah buaya $(\mathrm{Rp} / \mathrm{kg})$

$\mathrm{X} 2=$ Total biaya pupuk $(\mathrm{Rp} / \mathrm{kg} / \mathrm{bulan}$ proses produksi)

$\mathrm{X} 3=$ Total biaya pestisida $(\mathrm{Rp} / \mathrm{ltr} /$ bulan proses produksi)

$\mathrm{X} 4=$ Total biaya sewa lahan (Rp/luas lahan/bulan proses produksi)

$\mathrm{X} 5=$ Total biaya transportasi $(\mathrm{Rp} / \mathrm{bulan}$ proses produksi)

$\mathrm{X} 6=$ Total biaya tenaga kerja $(\mathrm{Rp} / \mathrm{HOK} /$ bulan proses produksi $)$

$\mathrm{X} 7 \quad=$ Total biaya pembelian peralatan $(\mathrm{Rp} / \mathrm{bulan}$ proses produksi)

$\mathrm{D}=$ Nilai biaya penyusutan peralatan $(\mathrm{Rp} / \mathrm{bulan}$ proses produksi)

e. Revenue Cost Ratio (R/C) 
$\mathrm{R} / \mathrm{C}$ ratio merupakan perbandingan antara penerimaan total dan biaya total, yang menunjukkan nilai penerimaan yang diperoleh dari setiap rupiah yang dikeluarkan. Untuk menganalisis tingkat efisiensi ekonomis usahatani digunakan rumus RCR menurut Hermanto (1993), yaitu :

$\mathbf{R C R}=\mathbf{T R} / \mathbf{T C}$

Keterangan:

$\mathrm{TR}=$ Total revenue (pendapatan kotor) $(\mathrm{Rp} / \mathrm{bulan}$ proses produksi $)$

$\mathrm{TC}=$ Total Cost (biaya total) $(\mathrm{Rp} / \mathrm{bulan}$ proses produksi)

Kriteria penilaian $\mathrm{R} / \mathrm{C}$ ratio:

$\mathrm{R} / \mathrm{C}<1=$ usaha tani lidah buaya mengalami kerugian

$\mathrm{R} / \mathrm{C}>1=$ usaha tani lidah buaya memperoleh keuntungan

$\mathrm{R} / \mathrm{C}=1=$ usaha tani lidah buaya mencapai titik impas

\section{HASIL DAN PEMBAHASAN}

\section{Pengadaan Sarana Produksi Lidah Buaya}

\section{Luas Lahan Petani Responden}

Kegiatan usahatani sangat ditentukan oleh sumberdaya tanah, misalnya luas lahan, tingkat kesuburan tanah, macam penggunaan. Semakin luas lahan usahatani maka hasil produksi diharapkan semakin tinggi, selain itu juga tingkat kesuburan lahan mampu memberikan peningkatan terhadap produksi usahatani tersebut.

Topografi wilayah juga menentukan kesuburan lahan. Tingkat kelerengan wilayah sangat menentukan tingkat kesuburan lahan. Lahan yang digunakan petani pada daerah penelitian umumnya memiliki topografi datar, berarti tingkat kesuburan tanah baik sehingga kesuburan tanah dapat dipertahankan karena tidak terjadi erosi oleh air penyiraman atau hujan yang dapat menyebabkan unsur hara hilang. Disamping itu pemberian pupuk organik pada tanah yang dilakukan setiap kali tanam memungkinkan tersedianya bahan organik yang dapat memperbaiki keadaan tanah. Luas lahan usahatani lidah buaya pada petani yaitu 0,5 ha pada kelompok Tani Panca Karya dan Kelompok Tani Karya Makmur. Status kepemilikan

91 Analisis Efisiensi Budidaya Tanaman Lidah Buaya Di Kelurahan Maharatu Kecamatan Marpoyan Damai Kota Pekanbaru 
lahan pada petani Kelompok Tani Panca Karya adalah lahan pinjam yang digunakan bersama oleh masyarakat tanpa dipungut biaya, sedangkan pada petani Kelompok Tani Karya makmur adalah lahan milik sendiri.

2. Penggunaan Pupuk dan pestisida

Pupuk yang digunakan oleh petani responden terdiri dari pupuk organik (Pupuk Kandang) dan pupuk buatan Urea, TSP, NPK dan KCL. Penggunaan pestisida bertujuan mengendalikan organisme pengganggu tanaman (OPT). Bila dipandang dari sudut ekonomi pengendalian dilakukan untuk menghindari kerugian ekonomi berupa kehilangan hasil (kuantitas) dan mutu (kualitas) produk (lidah buaya). Pestisida yang digunakan responden yaitu Drusban, Dithane Mas, dan Antrakol digunakan untuk membasmi hama yang menganggu tanaman lidah buaya. Biaya penggunaan mencapai jumlah Rp 145.500/musim tanam untuk kelompok tani Karya Makmur dan Rp 87.500/musim tanam untuk kelompok tani Panca Karya.

\section{Penggunaan Tenaga Kerja}

Sumber tenaga kerja yang digunakan petani dalam usahatani lidah buaya berasal dari dalam dan luar keluarga, yang terdiri dari pria dan wanita. Masing-masing tenaga kerja tersebut baik tenaga kerja dalam keluarga (TKDK) maupun tenaga kerja luar keluarga (TKLK) dinilai sama karena suatu usahatani dianggap sebagai biaya produksi yang di hitung berdasarkan Hari Kerja Pria (HKP) dengan konversi hitungan kerja 6 jam. Perhitungan tenaga kerja produksi dimulai dari pengolahan tanah, pembuatan bedengan, pemupukan awal, penanaman, pemeliharaan Upah tenaga kerja adalah Rp. 30.000/hari untuk tenaga kerja wanita sedangkan untuk upah tenaga kerja pria Rp. 50.000/hari.

Penggunaan tenaga kerja terbesar pada kelompok tani Karya Makmur yaitu pada tenaga kerja dalam keluarga, rata-rata kegiatan dilakukan oleh tenaga dalam keluarga sebesar 4,83 HKP/luas garapan/musim tanam untuk pria, 2,536 HKP/luas garapan/musim tanam untuk wanita dan tenaga kerja luar keluarga sebesar $2 \mathrm{HKP} / \mathrm{luas}$ garapan/musim tanam untuk pria, 0,16 HKP/luas garapan/musim tanam untuk wanita. Penggunaan tenaga kerja terbesar pada kelompok tani Panca Karya juga pada tenaga kerja dalam keluarga, yang mana rata-rata kegiatan dilakukan oleh tenaga dalam keluarga yaitu sebesar 6,67 HKP/luas garapan/musim tanam untuk pria, 2,96 HKP/luas garapan/musim tanam untuk wanita dan tenaga kerja luar 
keluarga sebesar $0 \mathrm{HKP} /$ luas garapan/musim tanam untuk pria, $0 \mathrm{HKP} / \mathrm{luas}$ garapan/musim tanam untuk wanita.

\section{Penggunaan Peralatan}

Peralatan yang digunakan petani responden dalam pelaksanaan usahatani lidah buaya terdiri dari beberapa alat pertanian seperti cangkul, parang, Alat semprot racun, gerobak, dan mesin pompa air. Semua alat-alat pertanian tersebut sangat mendukung kelancaran dalam proses usahatani lidah buaya dan mempunyai umur ekonomis atau masa pakai. Kondisi peralatan menunjukkan kesamaan antara dua kelompok tani. Nilai penyusutan alat-alat kelompok tani Karya Makmur yang paling besar yaitu penggunaan mesin pompa sebesar Rp 320.000 dan nilai penyusutan terendah pada yaitu parang sebesar Rp.21.000. Penyusutan alat petani kelompok tani Panca Karya yang terbesar yaitu mesin pompa dan alat semprot sebesar Rp 320.000 dan nilai penyusutan terendah yaitu parang sebesar Rp 8.000.

\section{Usahatani Lidah Buaya}

Pengelolaan usahatani lidah buaya akan memberikan hasil maksimal apabila menggunakan sarana produksi secara efisien. Biaya produksi meliputi biaya bibit, pupuk, pestisida, alat pertanian, tenaga kerja dan penyusutan alat pertanian. Usahatani yang dilakukan petani tujuan utamanya adalah meningkatkan produksi sehingga pendapatan yang diperoleh maksimal (Tabel 1). 
Tabel 1. Rata-Rata Usahatani Lidah Buaya Kelompok Tani Karya Makmur

\begin{tabular}{|c|c|c|c|c|}
\hline No & Uraian & Volume & Harga (Rp) & $\begin{array}{c}\text { Jumlah } / 0,5 \\
\text { ha }\end{array}$ \\
\hline \multirow[t]{27}{*}{1} & Biaya Produksi & & & \\
\hline & a. Variabel Cost (VC) & & & \\
\hline & *Bibit (pohon) & 500 & 8,000 & $4,000,000$ \\
\hline & $*$ Pupuk & & & \\
\hline & Kandang (karung) & 195 & 7,000 & $1,365,000$ \\
\hline & NPK (karung) & 2 & 105,000 & 210,000 \\
\hline & TSP (karung) & 2 & 105,000 & 210,000 \\
\hline & Urea (karung) & 1 & 200,000 & 200,000 \\
\hline & *Pestisida & & & \\
\hline & Dhitane Mas & 1 & 45,500 & 45,500 \\
\hline & Drusban & 2 & 50,000 & 100,000 \\
\hline & *Alat - alat Pertanian & & & \\
\hline & Cangkul & 3 & 30,000 & 90,000 \\
\hline & Parang & 2 & 20,000 & 40,000 \\
\hline & Alat Semprot & 2 & 400,000 & 800,000 \\
\hline & Gerobak & 1 & 200,000 & 200,000 \\
\hline & Mesin Pompa Air & 1 & $2,000,000$ & $2,000,000$ \\
\hline & *TKLK (HKP) & & & \\
\hline & TK Pria & 2 & 50,000 & 100,000 \\
\hline & TK Wanita & 0,16 & 30,000 & 4,800 \\
\hline & Jumlah & & & $9,365,300$ \\
\hline & b. Fixed Cost (FC) & & & \\
\hline & *Penyusutan & & & 857,000 \\
\hline & *TKDK (HKP) & & & \\
\hline & TK Pria & 4,83 & 50,000 & 241,500 \\
\hline & TK Wanita & 2,53 & 30,000 & 75,900 \\
\hline & Jumlah & & & $1,174,400$ \\
\hline 2 & Total Biaya Produksi & & & $10,539,700$ \\
\hline 3 & Biaya Produksi / 24 bulan & & & $439,154.16$ \\
\hline 4 & Pendapatan Kotor / bulan & 200 & 4000 & 800,000 \\
\hline 5 & Pendapatan Bersih & & & $360,845.84$ \\
\hline 6 & Efisiensi (RCR) & & & 1,82 \\
\hline
\end{tabular}

Sumber : Data Olahan

Pendapatan bersih petani kelompok tani Karya Makmur mencapai Rp.360.845,84/0,5 ha dengan harga jual lidah buaya Rp.4000/kg. Hasil produksi mencapai rata-rata 200 $\mathrm{Kg} /$ bulan dan total biaya produksi rata-rata selama 24 bulan mencapai Rp.439.154,16 dengan 
tingkat efisiensi (RCR) sebesar 1,82. Sedangkan petani responden kelompok tani Panca Karya dapat dilihat pada tabel 2.

Tabel 2. Rata-rata Usahatani Lidah Buaya Kelompok Tani Panca Karya

\begin{tabular}{|c|c|c|c|c|}
\hline No & Uraian & Volume & Harga (Rp) & $\begin{array}{c}\text { Jumlah } / \mathbf{0 , 5} \\
\text { ha }\end{array}$ \\
\hline \multirow[t]{27}{*}{1} & Biaya Produksi & & & \\
\hline & a. Variabel Cost (VC) & & & \\
\hline & *Bibit (pohon) & 250 & 8,000 & $2,000,000$ \\
\hline & *Pupuk & & & \\
\hline & Kandang (karung) & 150 & 7,000 & $1,050,000$ \\
\hline & NPK (karung) & 1 & 105,000 & 105,000 \\
\hline & TSP (karung) & 1 & 105,000 & 105,000 \\
\hline & Urea (karung) & 1 & 200,000 & 200,000 \\
\hline & *Pestisida & & & \\
\hline & Dhitane Mas & 1 & 45,500 & 45,500 \\
\hline & Drusban & 1 & 42,000 & 42,000 \\
\hline & *Alat - alat Pertanian & & & \\
\hline & Cangkul & 2 & 30,000 & 60,000 \\
\hline & Parang & 1 & 20,000 & 20,000 \\
\hline & Alat Semprot & 2 & 400,000 & 800,000 \\
\hline & Gerobak & 1 & 200,000 & 200,000 \\
\hline & Mesin Pompa Air & 1 & $2,000,000$ & $2,000,000$ \\
\hline & *TKLK (HKP) & & & \\
\hline & TK Pria & - & - & - \\
\hline & TK Wanita & - & - & - \\
\hline & Jumlah & & & $6,627,500$ \\
\hline & b. Fixed Cost (FC) & & & \\
\hline & *Penyusutan & & & 752,000 \\
\hline & *TKDK (HKP) & & & \\
\hline & TK Pria & 6,67 & 50,000 & 333,500 \\
\hline & TK Wanita & 2,96 & 30,000 & 88,800 \\
\hline & Jumlah & & & $1,174,300$ \\
\hline 2 & Total Biaya Produksi & & & $7,801,800$ \\
\hline 3 & Biaya Produksi / 24 bulan & & & 325,075 \\
\hline 4 & Pendapatan Kotor / bulan & 120 & 4000 & 480,000 \\
\hline 5 & Pendapatan Bersih & & & 154,925 \\
\hline 6 & Efisiensi (RCR) & & & 1,47 \\
\hline
\end{tabular}

Sumber : Data Olahan 
Tabel 2 menjelaskan bahwa pendapatan bersih petani kelompok tani Panca Karya mencapai Rp 154.925/0,5 ha dengan harga jual lidah buaya seharga Rp.4000/kg yang hasil produksi mencapai rata-rata $120 \mathrm{Kg} /$ bulan dan total biaya produksi rata-rata selama 24 bulan mencapai Rp 325.075 dengan tingkat efisiensi (RCR) sebesar 1,47.

\section{KESIMPULAN DAN SARAN}

\section{Kesimpulan}

Usahatani lidah buaya yang dilakukan pada Kelurahan Maharatu Kecamatan Marpoyan Damai yaitu pada dua kelompok tani yaitu Panca Karya dan Karya Makmur dengan luas lahan rata-rata seluas 0,5 Ha. Proses produksi tanaman lidah buaya selama sekitar satu tahun.

1. Usahatani yang dilakukan sudah cukup menguntungkan terbukti bahwa pendapatan bersih yang diterima petani Panca Karya sebesar Rp 154.925. dengan total produksi ratarata Rp 325.075 dan petani Karya Makmur Rp 360.845,84 dengan total produksi sebesar Rp 439.154,16 untuk satu kali produksi dalam satu bulan.

2. Hasil analisis diperoleh nilai RCR untuk usahatani lidah buaya petani pada kelompok tani Panca Karya sebesar 1,47 dan kelompok tani Karya Makmur sebesar 1,82 yang berarti bahwa setiap pengeluaran biaya Rp 100 untuk usahatani lidah buaya akan memberikan keuntungan sebesar Rp 147 untuk Panca Karya dan Rp 182 untuk Karya Makmur. Dengan demikian usahatani yang dilakukan petani lidah buaya di Kelurahan Maharatu Kecamatan Marpoyan Damai sudah cukup efisien.

\section{Saran}

1. Petani lidah buaya diharapkan lebih giat mempromosikan lidah buaya kepada konsumen tentang manfaat dan mempertimbangkan membuka lahan baru untuk usahatani lidah buaya.

2. Meningkatkan kerjasama dengan pihak terkait seperti dosen Fakultas Pertanian Universitas Riau untuk membantu mengembangkan lidah buaya yang ada di Kelurahan Maharatu Kecamatan Marpoyan Damai. 
3. Adanya perhatian dari pemerintah, swasta, lembaga perbankan dan instansi terkait terhadap usaha kecil menegah dalam menguatkan modal perkembangan usaha serta membantu peningkatan promosi di dalam negeri ataupun luar negeri.

\section{DAFTAR PUSTAKA}

Anonim. 2010. Pemasaran pertanian. Pekanbaru: Fakultas Pertanian Jurusan Agrobisnis Universitas Riau

Direktorat Jenderal Hortikultura. 2007. Pedoman Umum Pelaksanaan Pengembangan Agribisnis Hortikultura

Hermanto, F. 1993. IImu Usahatani. CV Penebar Swadaya. Jakarta

Ponto, S., Anderson Kumenanung dan Patrick Wauran. 2015. Analisis Korelasi Sektor Pertanian terhadap Tingkat Kemiskinan di Kabupaten Kepulauan Sangihe. Jurnal Berkala Ilmiah Efisiensi Vol. 15(4):137-147.

Rajagukguk, S.I., Meneth Ginting dan Ernalisa. 2013. Partisipasi Petani dalam Program Pengembangan Agribisnis Pedesaan (PUAP). Journal on Social Economic of Agriculture and Agribusiness Vol. 2(1):1-15

Soemarsono, M.S. 2002. Rancang Bangun Pengembangan Wilayah Agribisnis. Trenggalek, Jawa Timur.

Sumodiningrat, G. 2000. Pembangunan Ekonomi Melalui Pengembangan Pertanian. PT.Bina Rena Pariwisata, Jakarta.

Soekartawi. 2002. Ilmu Usahatani. Universitas Indonesia Press, Jakarta

Soekartawi. 1995. Prinsip Dasar Ekonomi Pertanian.Teori dan Aplikasinya. PT. Raja Grafindo Persada. Jakarta.

Zulfita, D. 2012. Kajian Fisiologi Tanaman Lidah Buaya dengan Pemotongan Ujung Pelepah pada Kondisi Cekaman Kekeringan. Jurnal Perkebunan \& Lahan Tropika, Vol. 2(1):7-14 